\author{
KALINA SKÓRA
}

\title{
A HABIT OF PROVIDING THE DEAD WITH PADLOCKS AGAINST THE BACKGROUND OF ASHKENAZI FUNERAL RITES
}

\begin{abstract}
This paper discusses a habit of providing the dead with padlocks, which was widespread in the Jewish population in Central-Eastern Europe. The main source of data for this habit are archaeological examinations. Defining the origin of this rite seems problematic. The habit was discussed against the broad background of Ashkenazi funeral rites, in reference to religiously founded beliefs related to the dead and the death, as well as to popular folk beliefs, which are known from pioneering ethnographic works from the $19^{\text {th }}$ and the early $20^{\text {th }} \mathrm{c}$. An attempt at characterising this phenomenon in a multi-aspect manner was undertaken. Attention was paid to a possibility of mutual intermingling of elements of Jewish and Slavic folk culture with regard to anti-demonic and anti-epidemic remedies.
\end{abstract}

Keywords: Ashkenazi Jews, funeral rites, padlocks, archaeological examinations, folk culture, Middle Ages, Modern Period

The culture of the European Jews in the aspect of its funeral rites is a subject of archaeological and ethnographic research. In the recent years, archaeological research has not usually been undertaken any more ${ }^{1}$, due to respect to principles of intangibility of burials ${ }^{2}$, which are founded in religious laws. Therefore, what remains as a source of information are results of previous archaeological examinations and incidental finds. On the other hand, ethnographic research is founded upon achievements of pioneers of research on Jewish culture from the late $19^{\text {th }}$ and the early $20^{\text {th }}$ c. Furthermore, ethnography faces now the problem of passing away of witnesses of interrupted tradition, and it even deals with attempts at reenacting and continuing it in ultra-Orthodox families ${ }^{3}$.

1 In all probability, only few Medieval Jewish cemeteries have been examined so far in a more or less comprehensive manner. These are, e.g., York in England and Montjuïc near Barcelona - Harck 2004, 30.

2 On the other hand, exhumation is allowed, provided that its aim is to transfer the dead body to Israel - Harck 2014, 345; de Vries 2000, 367. Being intact, the dead in burials await the coming of the Messiah (Bones in the grave will be rolling under the ground, until they roll to the holy city - Lilientalowa 1902, 352). It was recommended to even bury amputated limbs in the cemetery - Lilientalowa 1904, 109. However, violation of the principle of graves' inviolability and of preservation of dead bodies' integrity is confirmed in sources. There occurred exhumations and burning of dead bodies of persons who were suspected of causing the plague. Cremation was intended to prevent it - Tuszewicki 2015, 457, with literature references in footnote 65 .

3 Wilczura 2010, 40.
Jewish culture and rules of daily life, which were shaped by the Biblical-Talmudic tradition, were not undergoing radical changes in the course of centuries in the Polish lands. On the other hand, the $19^{\text {th }} \mathrm{c}$. witnesses a process of socio-economic and cultural (also religious) transformations, which are a resultant of a more and more popular idea of getting closer to the Polish and European culture ${ }^{4}$. These transformations also concerned funeral rites, which were defined by a commonly used code of rabbinic law - the Shulchan Aruch $^{5}$. The Jewish population must have faced a dilemma between fidelity to their own tradition and loyalty to the state. This was said by Leszek Hońdo in the context of the situation of the population of Kraków, who were subject to legislation of the Austrian state, which was introducing new sanitary and public order rules ${ }^{6}$. Objections were provoked by new regulations which ordered to secure dead bodies which were transported to the cemetery and to bury them in coffins, instead of traditionally used planks and a lid, which were to protect the dead against disgracing contact with

\section{Hońdo 2011, 7.}

Goldberg-Mulkiewicz 1986, 103.

6 Hońdo 2011, 8. Administrative authorities required transportation of the dead body to the cemetery in a coffin. Furthermore, the burial was to be done only after 48 hours after the declaration of death. This was contradictory to the Jewish tradition, in which the body was carried on an open bier, or often on a plank or a ladder, without using a cart. Furthermore, the burial had to take place within 24 hours after the death - Hońdo 2011, 56,60 . 


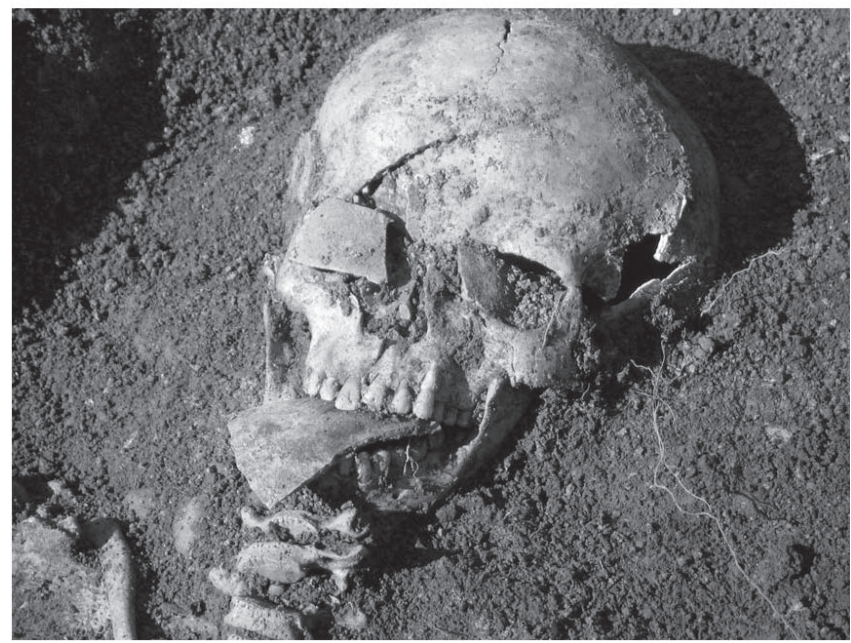

Fig. 1. Burial from a Jewish cemetery in Slavkov near Brno. After Mikulkova 2011, Fig. 18.

earth being thrown on them ${ }^{7}$. Furthermore, according to folk beliefs, the coffin could be an obstacle in the resurrection ${ }^{8}$. The turn of the $19^{\text {th }}$ and $20^{\text {th }}$ c. can also be seen as a period of co-occurrence of funeral customs which were present both in folk and in high culture. Furthermore, it was a period when many aspects of life yielded to the influence of modernity ${ }^{9}$.

At the same time, high mortality rate of children and plagues taking their abundant toll invariably provoked anxiety within the community. As common people generally lacked trust in official medical knowledge which was spreading in the $19^{\text {th }} \mathrm{c}$., there was still strong interest in traditional practices used to marginalise the danger of death ${ }^{10}$. This reluctance, which sometimes grew during epidemics and which received support from Chassidic groups, also meant incessant popularity of folk medicine and magical gestures ${ }^{11}$. When the first victims of a plague were recorded, various activities toward the dead or within cemeteries were undertaken as effective means to stop the disease.

\section{Beliefs related to the dead and the death}

In traditional imagination of the Jewish population the time of death was dangerous both for the dead person and the mourners. Obviously, this idea was not originally Jewish and it was rather typical for pre-modern cultures, whose community tried to separate the spheres of life and death, of the world of the living and the dead ${ }^{12}$. Contact with the

\section{Hońdo 2011, 20.}

8 Fijałkowski 1989, 34.

9 It was possible to preserve the habit of not using coffins, which was widespread among the Ashkenazi Jews (as it is assumed, under the influence of Kabala), to the end of the $19^{\text {th }} \mathrm{c}$. At that time, assimilating groups of wealthy part of the Jewish population, including believers of reformed Judaism, adopted the habit of using coffins more easily - Fijałkowski 1989, 34; Fijałkowski 2003, 363.

10 Libera 2003, 202-248; Tuszewicki 2015, 55.

11 Tuszewicki 2015, 120.

12 Tuszewicki 2015, 476-477. dead body ${ }^{13}$, or even with items belonging to the dead was considered dangerous. Caution was recommended at each stage, from the time of agony via activities preparing the dead person for burial to the return from the cemetery ${ }^{14}$. Even unintentional imitation of practices related to preparation of burial in daily life could cause health problems or even death ${ }^{15}$. What was in contrast to these folk beliefs were rituals which were followed during weddings and which were related to mourning - putting funeral robes on by the bridegroom or a tradition of the „dance of death” during the wedding reception ${ }^{16}$. Each stage of the ritual cycle of life in the Jewish community brought such a danger and a risk of influence from supernatural powers.

With regard to that, in order to avoid the danger of a sudden death of the next member of the community or to prevent attacks of unclean powers, it was necessary to undertake a series of preventive means. These were rooted in Halacha and in customs and their aim was to secure peace for the community and for the dead person. These activities had a profound symbolic meaning - they closed the earthly way and prepared the dead person to meet the Messiah.

In the Jewish population, analogously to their Slavic neighbours, there was a belief that circumstances and the kind of death were conditioned by righteousness of the dead person. Long agony in suffering, sudden and unnatural death was meant for sinners, while those who were morally pure passed away in peace ${ }^{17}$.

A list of practices of apotropaeic or even anti-demonic nature which were intended to protect the living and which are known from ethnographic sources is very abundant. Some of these can be interpreted in a similar manner to Slavic folk beliefs - for instance, a belief in a harmful effect of the sight of the dead person was analogous in both populations. Closing the eyes and the mouth of the dead protected the community against new deaths ${ }^{18}$. It is evidenced in both traditions that the dead person was placed on the floor with his or her legs and face toward the door ${ }^{19}$, or that it was avoided to make knots or kinks in the funeral clothes of the dead ${ }^{20}$.

13 Paradoxically, in the light of some superstitions the dead body had a power which was able to heal or, e.g., to stop the fire, while earth from the cemetery was believed to be a remedy for some diseases - Lilientalowa 1904, 111-112; Tuszewicki 2015, 178, 463.

${ }_{14}$ After the burial relatives returned home using a different road than that on which they arrived - Pakentreger 1987, 43.

15 For this reason it was recommended to avoid leaving through the window or keeping broken vessels at home, sleeping in shoes or on the table - Tuszewicki 2015, 477.

16 Elior 2014, 97-99.

17 Lilientalowa 1904, 108-109; Pakentreger 1987, 41.

18 Cf. Lilientalowa 1904, 107; Fischer 1921, 120-126; Biegeleisen 1930, 141-142; Tuszewicki 2015, 456.

19 Pakentreger 1987, 41; Hońdo 2011, 16; cf. Fischer 1921, 254-255; Biegeleisen 1930, 157-158, 161.

20 Fischer 1921, 111-118. In traditional culture, folds or knots are places of residence of unclean forces - Tuszewicki 2015, 349, 459. 

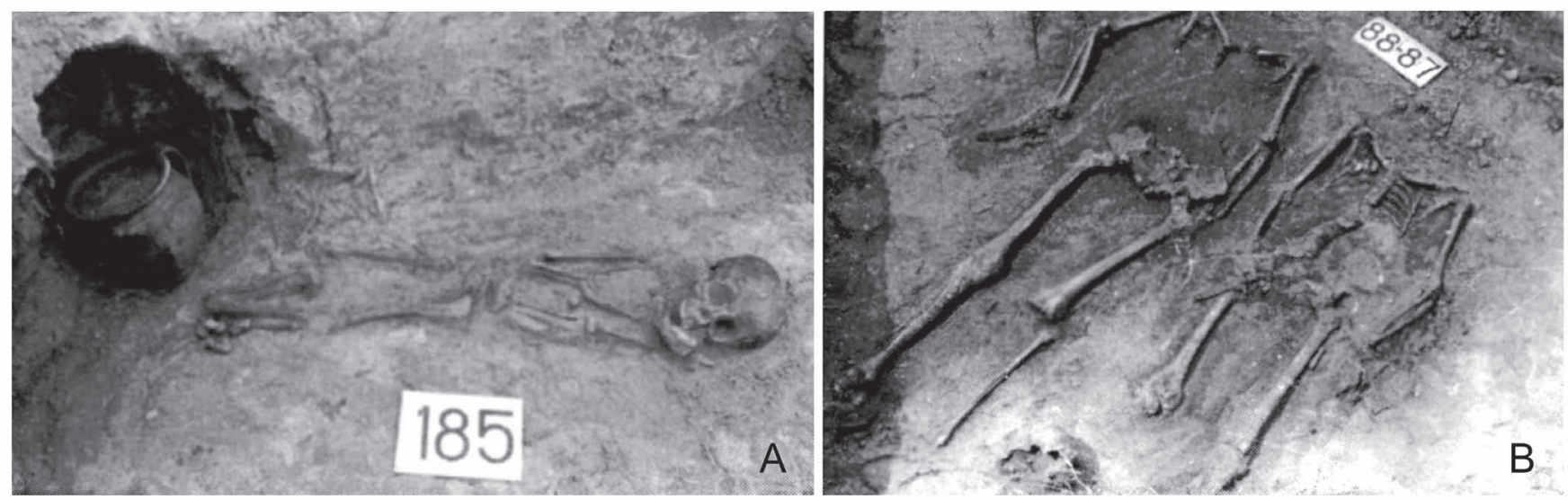

Fig. 2. Jewish cemetery in Brześć Kujawski: A. Burial (No. 185) of a child with a vessel. B. Men buried with knives in their hands, Graves 87 and 88. After Borowska-Strugińska 2005, Figs. 5-6.

According to the Jewish tradition, it was necessary to take care of ritual purification - tahara (טהרה) and of the clothes of the dead person. In the end of the ceremony of washing, a cup (jug) was broken, in which there was wine mixed with egg ${ }^{21}$. The egg is mixed in the cup as a symbol of the wheel of human fate, which turns around on earth...22. A repeated use of vessels which were once used for this purpose was prohibited. Therefore, such vessels were especially bought for this occasion ${ }^{23}$. In general terms, it was not recommended to bring items from the world of the living to the cemetery and a reverse direction of travel of an artefact was also potentially dangerous. In case the dead person was flatulent, black bread with salt, a key or a small tin plate was placed on his or her belly ${ }^{24}$. These objects were also remedies against unclean forces. A ,tenner” and earth from Eretz Yisrael were placed on the mouth of the dead ${ }^{25}$.

The dead person should not be anyhow distinguished with symbols of his or her social status ${ }^{26}$. The robe was supposed to be identical for each dead. It was to be modest, without ornaments, made from white linen and sewn with large stitches without knots. As it was forbidden to use scissors, linen was torn for this purpose. Threads were not torn, but were burnt through over a candle ${ }^{27}$. Clothes could not have pockets, as these symbolised wealth. The lack of pockets meant that good acts were more important ${ }^{28}$. No piercing or staining of robes was allowed. The mouth of the dead person was secured with a towel for this purpose. This towel was then also deposited into the grave ${ }^{29}$. A habit of dressing

${ }^{21}$ According to A. Pakentreger, it served to offer a purification drink to the dead person - Pakentreger 1987, 42.

22 Hońdo 2011, 17. A symbolic meaning of this act is stated after Ganzfried 1973, Chapter 197.

23 Tuszewicki 2015, 458-459.

24 Lilientalowa 1904, 107.

25 According to folk beliefs, this earth had properties which repelled worms from the mouth - Tuszewicki 2015, 460.

26 Blanchard and Georges 2010, 52.

27 Goldberg-Mulkiewicz 1986, 104; Pakentreger 1987, 41.

28 Hońdo 2011, 18.

29 Hońdo 2011, 19. the dead in tallit and tefillin made them ready for prayer $^{30}$. In the case of women the dress differed depending on the marital status. With regard to that, there were separate requirements for women died at childbirth. A short black skirt was put under their shirt, and they were also given leather shoes with soles studded with small iron hobnails ${ }^{31}$.

While sawing planks or making coffins it was necessary to burn production waste. Coffins which had contact with the dead person but proved too small, also had to be burned or buried ${ }^{32}$. It was acceptable to use them to heat water for washing the body ${ }^{33}$. The dead were placed in graves on their backs, with their faces up. If possible, earth from Eretz Yisrael is put under the dead and on their mouth, eyes and hands, and - in the case of men - on the place of circumcision $^{34}$.

Bodies of women who died at childbirth were not washed and blood which they lost until the moment of death also had to find its way into the grave. The same concerned all objects which had contact with blood, clothes, and parts of their beds ${ }^{35}$. Dead bodies were covered with bed sheets, and funeral clothes were deposited into the grave next to puerperae. In some Jewish communes it occurred that funeral clothes were put on the dress of dead women ${ }^{36}$.

Such procedures as, e.g., grasping one's ear or offering alms to members of the funeral brotherhood were to protect mourners against death ${ }^{37}$. Furthermore, the sound of striking at metal cans by members of the brotherhood was to repeal demons ${ }^{38}$.
30 Fijałkowski 1989, 33.

31 Hońdo 2011, 19.

32 Hońdo 2011, 21.

33 Ganzfried 1973, Chapter 199.

34 Hońdo 2011, 21.

35 The same concerned victims of murders. Even earth touched by blood of the victim was deposited into the grave - Hońdo 2011, 22 .

36 Hońdo 2011, 21.

37 Lilientalowa 1904, 109.

38 Tuszewicki 2015, 465. 


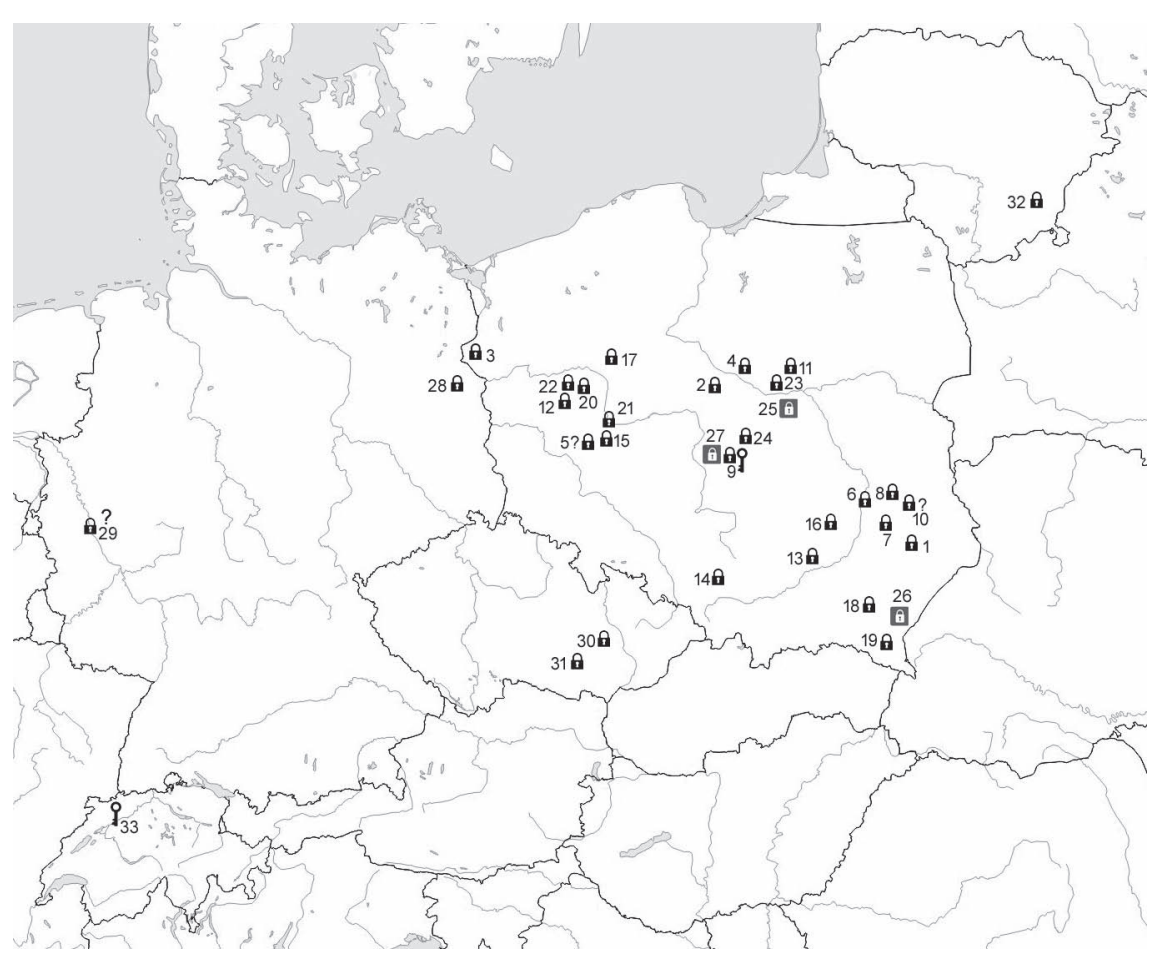

Fig. 3. Map of the territorial distribution of discoveries of padlocks and keys from Jewish cemeteries in Central Europe. Black - archaeological discoveries. Grey - habit evidenced by oral relations. By K. Skóra. After Komski et al. 2014, with corrections and additions by the author. 1. Biłgoraj; 2. Brześć Kujawski; 3. Cedynia; 4. Dobrzyń nad Wisłą, 5. Górsko (?); 6. Kazimierz Dolny; 7. Kraśnik; 8. Lublin; 9. Lutomiersk; 10. Piaski (?); 11. Płońsk; 12. Pniewy; 13. Połaniec; 14. Olkusz; 15. Osieczna; 16. Ostrowiec Świętokrzyski; 17. Rogoźno; 18. Rzeszów; 19. Sanok; 20. Szamotuly; 21. Śrem; 22. Wronki; 23. Wyszogród; 24. Zgierz; 25. Sochaczew; 26. Przemyśl; 27. Szadek; 28. Buckow; 29. Köln; 30. Prostějov; 31. Slavkov; 32. Vilnius; 33. Basel.

During the funeral a member of the „Chevrah Kadisha” placed the dead body into the grave and, provided that the dead was a married man, covered his eyes and mouth with shards of a broken jug, in which there was wine mixed with egg $^{39}$. Eyes and mouth were protected in such a way due to their inclination to sin during one's life ${ }^{40}$. A small wooden fork ${ }^{41}$, that is a piece of a dry twig (Yiddish - gepelich; (געפליך) was placed in the hand of the dead. Some interpretations considered this a superstition ${ }^{42}$. It was believed that this twig was to help the dead person purify oneself or raise in the day of coming of the Messiah ${ }^{43}$. A padlock was put into the grave.

\section{Archaeological traces of Ashkenazi funeral rites}

Not all of the afore-mentioned elements which make up the image of funeral rites are confirmed by archaeological research. Conversely, archaeology reveals poorly identified aspects of rites, whose significance is difficult to explain due to the lack of information in written sources and perhaps due to the fact that they existed only in folk practices, with no religiously founded interpretation ${ }^{44}$. The latter difficulty is exemplified by padlocks recorded in burials. Analogously to shards of vessels, these are the most commonly found remains of funeral habits of the Ashkenazi Jews in Poland. It seems that they were recorded in all necropoles from the

39 Hońdo 2011, 17, 29.

40 Fijałkowski 1989, 34; Hońdo 2011, 29.

41 Lilientalowa 1898, 278.

42 Hońdo 2011, 29; Tuszewicki 2015, 460.

43 Hońdo 2011, 29.

44 For instance, in Halle an der Saale a joint burial of a human and a dog was found, which was alien to the Jewish tradition (Site 94, Graves 1.2 and 1.10) - Harck 2014, 360. territory of the Old Commonwealth of Both Nations which were archaeologically examined ${ }^{45}$.

The assortment of objects which were allowed to find their way into the grave was strictly defined. Deviations from the traditional canon are rarely recorded. Therefore, archaeological traces of funeral rites are usually modest. Due to their complexity, the following aspects will not be discussed here: alignment of burials, organisation of the cemetery's space and a related issue of respecting the principle of mutual non-disturbance of burial pits ${ }^{46}$, a prohibition of burying more than one dead person in a grave pit ${ }^{47}$, or laying out cemeteries en terre vierge $e^{48}$. We will focus on other manifestations of funeral rites. Within the group of elements discovered in Ashkenazi cemeteries which are related to deposition of dead bodies into grave pits there are first of all remains of planks coming from linings (Maków Mazowiecki, Krasiczyn, Dobrzyń upon the River Wisła). Nails are also revealed, which demonstrates that - contrary to official recommendation - linings were fastened with nails (Dobrzyń upon the River Wisła, Lublin ${ }^{49}$, Wyszogród ${ }^{50}$, Praha, Vladislavova Street, the Jewish Garden ${ }^{51}$, Meißen in Saxony, Ulm in Baden-Württemberg, Regensburg in

45 Fijałkowski 1989, 34

46 Such cases are recorded archaeologically - this, however, rather concerns mutual disturbance of pits and not of skeletons as such - cf. Blanchard et al. 2009, 21.

47 Blanchard and Georges 2010, 48.

48 Blanchard et al. 2009, 19.

49 Fijałkowski 1989, 27.

50 Fijałkowski 2003, 363.

51 Wallisová 2009, 56; Vyšohlíd 2013; Cymbalak et al. 2015, 157; cf. Wallisová 2011. 

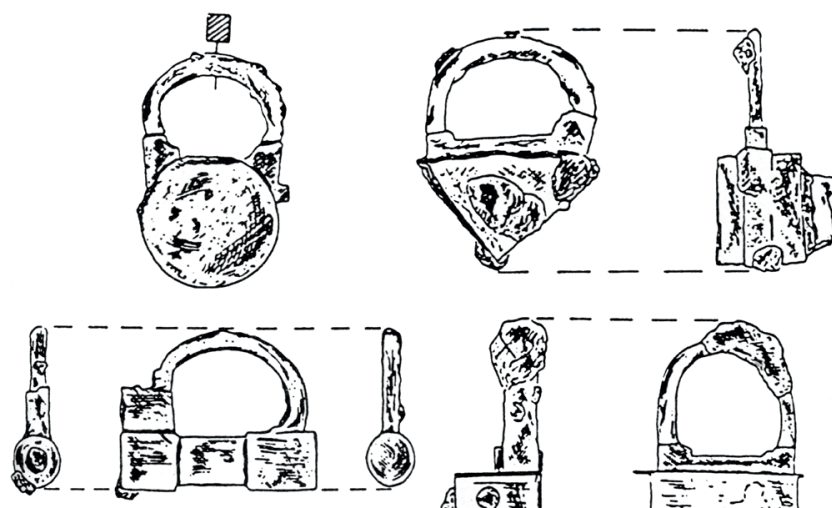

$10 \mathrm{~cm}$

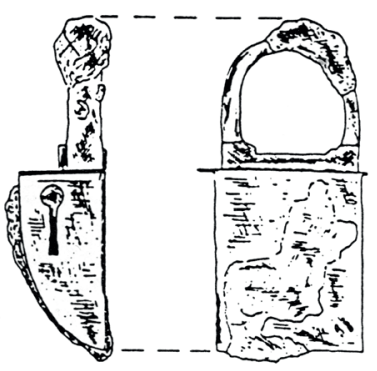

Fig. 4. Padlocks discovered in the Jewish cemetery in Wilno. After Žukovskis 2000, Fig. 5.

Bavaria $\left.^{52}\right)$. The presence of nails can also suggest the use of coffins (York, „Judenbüchel” to the south of Köln ${ }^{53}$, Rostock, Krems $^{54}$, or Basel ${ }^{55}$ ).

Sometimes it is possible to record remains of pillows with earth under skulls (Brześć Kujawski, Lutomiersk, Basel) ${ }^{56}$. It is assumed that this earth comes from Eretz Yisrael. As it turned out in result of specialist analyses in the case of Basel, the earth in fact came from the vicinity of the city ${ }^{57}$. In the light of what A. Pakentreger says, such pillows were filled with sand from the grave with admixture of earth from Eretz Yisrael ${ }^{58}$. As stated by the authors of the analysis, such symbolic admixture is difficult to identify in the course of research ${ }^{59}$.

Remains of clothes of the dead person are very rarely found in Ashkenazi cemeteries ${ }^{60}$. This on the one hand results from funeral rites, and on the other hand is due to decomposition of organic materials. However, what is recorded are metal buckles (Basel ${ }^{61}$; Praha, Vladislavova Street No. 1390) and textiles: remains of headbands, silk threads and cloth of gold from veils (Basel ${ }^{62}$, Praha, Vladislavova Street ${ }^{63}$ ), as well as headgear (Köln, Praha, Bartolomějské Street ${ }^{64}$ ).

52 Harck 2014, 372.

54 Harck 2004, 31.

55 Alder and Matt 2010, 33-34.

56 Borowska-Strugińska 2005, 236.

57 Pümpin and Rentzel 2010, 36-38.

58 Pakentreger 1987, 42.

59 Pümpin and Rentzel 2010, 38.

60 Ornaments and parts of dress are more often recorded in cemeteries of the Sephardic Jews - cf. Alder and Matt 2010, 31, footnote 104; Blanchard and Georges 2010, 52, e.g., buckles in Châteauroux - Blanchard and Georges 2010, 41, headgear in Montjuïch - Harck 2004, 33.

61 Alder and Matt 2010, 29.

62 Alder and Matt 2010, 32, Fig. 13.

63 Wallisová 2009, 57; Wallisová 2011; Cymbalak et al. 2015, 158.

64 Wallisová 2009, 58 - with relevant literature.
We also find coins deposited with the dead (Brześć Kujawski $^{65}$, Lublin, Lutomiersk ${ }^{66}$, Base ${ }^{67}$ ). At Lublin, it was even proved that old coins were used - a dead person had a hidden $11^{\text {th }} \mathrm{c}$. cross denar in clothes, together with $18^{\text {th }} \mathrm{c}$. coins $^{68}$.

Rare discoveries include scissors (Zwingen, Basel District $^{69}$ ) or Slavic temple rings (Halle an der Saale, SaxonyAnhalt $)^{70}$, which could be material evidence for mixed marriages in the Middle Ages ${ }^{71}$. A seal belonging to a Jew named Muskinus (died in 1336) was found in the cemetery in Trèves ${ }^{72}$. Knives are also sparse. They were discovered in Basel $^{73}$ and in Brześć Kujawski. In the latter cemetery these artefacts were in the right hands of two men, died at the age of 30-40 and 40-50, who were buried next to each other ${ }^{74}$ (Fig. 2:B). It is difficult to guess how to justify the presence of tools in the grave. According to B. Borowska-Strugińska it is possible that this is a burial of people dealing with ritual slaughter (shoihet in Yiddish) ${ }^{75}$.

On the other hand, what is commonly found are shards of vessels (Fig. 1), which were placed on the eyes, more sporadically in the mouths ${ }^{76}$ or on the mouths of the dead (Dobrzyń upon the River Wisła, Krasiczyn, Maków Mazowiecki ${ }^{77}$, Płońsk, Połaniec, Lutomiersk ${ }^{78}$, Wyszogród). In Lublin it was noticed that shards were processed and were shaped as discs, triangles, trapezes and rectangles (these were usually placed on the mouth $)^{79}$. A similar habit was identified, among others, in the $18^{\text {th }}$ c. cemetery in Wilno (shards were shaped as discs or crescents ${ }^{80}$ ) or in Slavkov near Brno (trapezoid shape) ${ }^{81}$.

It sometimes occurs that different raw material is used for this purpose, namely, processed stone plates from schist $\left(\mathrm{a} 13^{\text {th }}-14^{\text {th }}\right.$ c. cemetery, Praha, Vladislavova Street ${ }^{82}$,

65 Borowska-Strugińska 2005, 235.

66 Fijałkowski 1989, 29.

67 Alder and Matt 2010, 29.

68 Fijałkowski 1989, 26-27.

69 Nordmann 1906, 18.

70 In one grave a Slavic temple ring from the $2^{\text {nd }}$ half of the $11^{\text {th }} \mathrm{c}$. was discovered. O. Harck proposes that it may be a family ornament, taken into the grave by a Slavic woman who was married to a Jew - Harck 2014, 359, Fig. 151.

71 Marriages of this kind are confirmed in written sources, also including inscriptions on matzevas (e.g., Berlin-Spandau, Worms, Brno - Lieben 1933; Harck 2014, footnote 184).

72 Clemens 2009, 165.

73 A small iron knife with a broken blade and a damaged handle was found in a male grave (mohel?) - Alder and Matt 2010, 33, Figs. 17-18.

74 Borowska-Strugińska 2005, 235-236, Fig. 6.

75 Borowska-Strugińska 2005, 236.

76 Fijałkowski 1989, 27.

77 Fijałkowski 2003, 363.

78 Fijałkowski 1989, 29.

79 Fijałkowski 1989, 28.

80 Žukovskis 2000.

81 Mikulkova 2011, 32, Fig. 18.

82 Wallisová 1998, 2; Cymbalak et al. 2015, 157-159. 
Jungmannova Street No. 26 ${ }^{83}$ ). Shards of vessels covering the eyes are very numerous in Jewish cemeteries from the Polish lands ${ }^{84}$. This habit is archaeologically confirmed in Bohemia $^{85}$, Lithuania ${ }^{86}$, and Germany ${ }^{87}$ and probably also in France ${ }^{88}$. We can suppose that this habit has a long tradition which dates back to the Middle Ages and lasts to the Modern Period, and in the Polish lands even to the first decades of the $20^{\text {th }}$ c. ${ }^{89}$ Breaking of vessels in cemeteries is confirmed both by oral tradition and archaeology ${ }^{90}$.

A discovery of complete vessels at Brześć Kujawski in burials of two men and a child died at the age of 8 is exceptional (Fig. 2:A). These artefacts were placed near the feet of the dead. B. Borowska-Strugińska explains the presence of these finds with the provenance of the dead from the Tribe of Levi. As persons who were responsible for ritual purity of sacred vessels, they were washing the hands of priests ${ }^{91}$. Bowls and jugs used for this purpose are depicted on tombstones of men from this tribe ${ }^{92}$. The uniqueness of this discovery and forms of the vessels discovered in these burials does not fit into this interpretation. Although this habit is difficult to explain in a different manner, an explanation should rather be sought beyond official interpretation, that is, in folk beliefs.

A special group of artefacts discovered in Jewish graves are keys (Lutomiersk ${ }^{93}$, Zwingen $^{94}$, Tarrega ${ }^{95}$ ) and padlocks. In the light of archaeological documentation it can be assumed that padlocks were most often placed near the heads of the dead (i.a., Buckow Märkisch-Oderland District $^{96}$, Lutomiersk ${ }^{97}$ ). On the other hand, it is also evidenced that padlocks were deposited near the pelvis or femora (e.g., Lublin ${ }^{98}$, Wyszogród ${ }^{99}$ ). It is sometimes possible to see a relation between the size of padlocks and the

83 Cymbalak et al. 2015, Fig. 9.

84 Piotrowski 1987; Skrok 1991; Skrok 1994; BorowskaStrugińska 2005 .

85 Wallisová 2009, 60.

86 Žukovskis 2000.

87 Harck 2014, 373.

88 Alder and Matt 2010, 35, footnote 121.

89 This habit is testified to i.a. in the cemetery in Höxter, North Rhine-Westphalia, which was used since 1640. At this site shards of vessels were found on the eyeholes of the dead (Harck 2014,373 ). The same was noticed at Prostějov in $17^{\text {th }}-18^{\text {th }}$ c. burials (Čižmář and Šmíd 2000, 94).

90 Fijałkowski 2003, 364.

91 Borowska-Strugińska 2005, 235.

92 Rozmus 2005, 223-225.

93 Fijałkowski 1989, 29.

94 Nordmann 1906, 18.

95 A key and coins discovered at Tarrega in Spain were found in a multiple burial and not strictly as part of grave furnishings, but because they were left in daily clothes in the course of the burial after a pogrom which took place in 1348 - Blanchard and Georges 2010, 52.

96 Krügel and Kirsch 2005/2006, 289.

97 Nadolski et al. 1959, 11; Fijałkowski 1989, 29.

98 Fijałkowski 1989, 27.

99 Fijałkowski 1989, 32. age of the dead, that is, small padlocks were deposited into graves of children ${ }^{100}$. This, however, is not a rule $\mathrm{e}^{101}$. There seems to be no dependence between using this habit and the sex or age of the dead. It is worth noting that giving padlocks to the dead was not mandatory. This is evidenced by diversified numbers of these artefacts revealed in cemeteries. As there are no necropoles which were completely examined it is impossible to compare numerical data. So far, the assemblage from Lutomiersk is the largest one in Poland ${ }^{102}$. In total, almost 400 padlocks were acquired from about 1200 graves $^{103}$.

Based on the analysis of the territorial distribution of cemeteries it can be said that this habit was in use among the Ashkenazi Jews, but mainly in the territory of present-day Poland (Fig. 3). On the basis of archaeological examinations it can be assumed that the maximum eastern range of this habit can be recorded in Wilno (Fig. 4) ${ }^{104}$, while in the West it reached Buckow in Brandenburg (Fig. 5) ${ }^{105}$. It is possible that the western border of this habit's range can be moved as far as Köln. This is, however, not certain, because the issue of chronological and cultural classification of these discoveries

\footnotetext{
100 Krügel and Kirsch 2005/2006, 289-290.

101 Cf. Piotrowski 1987, 234.
}

102 Nadolski et al. 1959, 11.

103 The chronology of the assemblage of finds from Lutomiersk is not obvious. It should fall within the period of use of the cemetery - this period, however, is not certain. P. Fijałkowski dates the beginning of the Jewish commune and the cemetery to the mid-18 ${ }^{\text {th }}$ c. (Fijałkowski 1989, 29). However, in the light of written sources the presence of the Jewish community in Lutomiersk is testified to as early as the beginning of the $17^{\text {th }} \mathrm{c}$. The first Jew who was recorded in municipal books is Samuel Hebreń, who bought the Złotnikowski house in Lutomiersk in 1609 - Głą 2015, 306. Cf. also Spector, Wigoder (eds.) 2001, 758; Głąb 2015, 23, 110, $117,132,140$. Therefore, it is possible that the arrival of the first Jewish settlers took place earlier, already in the $16^{\text {th }} \mathrm{c}$. On the other hand, written sources say that the Jewish cemetery existed as early as the mid- $17^{\text {th }} \mathrm{c}$. Records from that time inform about a garden bordering the Kierchel Żydowski (Jewish cemetery) - Głąb 2015, 282,285 . As it is known, before 1811, when the first Jewish cemetery in Łódź in Wesoła Street was opened, it was the necropolis in Lutomiersk that was a burial ground for the Jewish population from Łódź - Podgarbi 1990, 10. The time of consecration of the cemetery is depicted in a different manner in Pinkas hakehillot Polin (p. 148-150). This fact, and the establishment of the „Chevrah Kadisha” funeral brotherhood were believed to take place only in the early $18^{\text {th }} \mathrm{c}$. At the end of this century a wooden synagogue was built. In the light of municipal books the time of construction of the first synagogue can be moved to the early $18^{\text {th }}$ c. In 1695 Piotr Markowicz sold Wilczkowski Square to the Jewish commune - Judeis omnibus in civitate Lutom [irsko] existentibus ac toti Synagogae Lutomir[iensi] Judaicae. This square was used for the construction of the synagogue. It is first mentioned in sources in 1731 - Głąb 2015, 307.

104 Žukovskis 1998, 441-443; Žukovskis 2000, Fig. 5.

105 Krügel and Kirsch 2005/2006, 289-296, Fig. 1. 

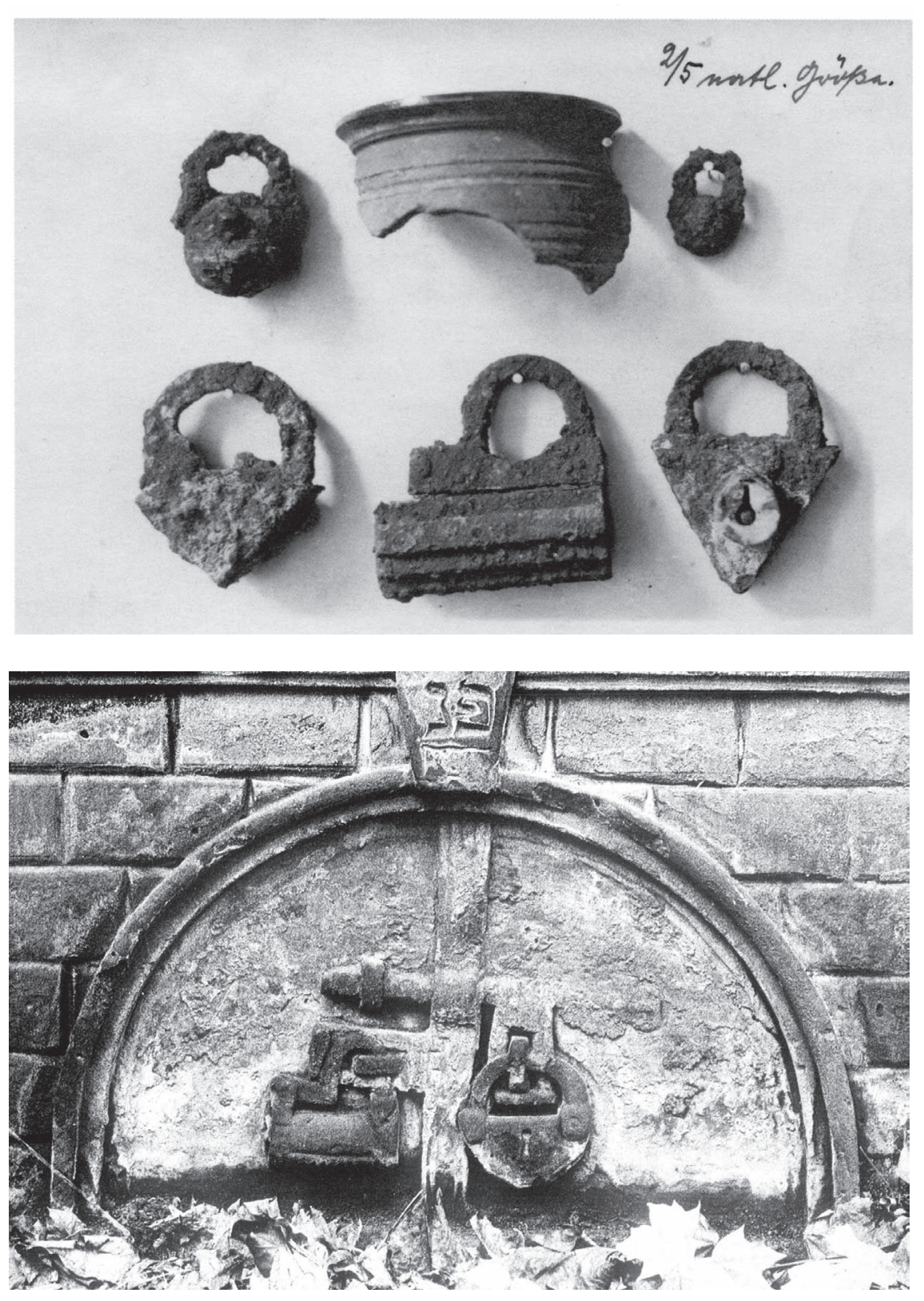

Fig. 5. Padlocks and a fragment of a clay vessel from the Jewish cemetery in Buckow in Brandenburg. After Krügel and Kirsch 2005/2006, Fig. 1. is problematic ${ }^{106}$. Padlocks were also recorded in two necropoles in Bohemia - these are Prostějov, Šerhovni Street (a cemetery from the $17^{\text {th }}-18^{\text {th }}$ c. $)^{107}$ and Slavkov near Brno, Čs. armády Street (a cemetery which was in use to the mid$18^{\text {th }}$ c. $)^{108}$.

In general terms, it can be assumed that the territorial range of the habit of putting padlocks into graves was broader than it is suggested by archaeological research in Central Europe.

106 On the basis of the nature of finds from burials a Jewish identity of the dead can be assumed. A premise for this are iron fittings of coffins, which are similar to those discovered in the necropolis in York in England - Lilley et al. 1994. Furthermore, surviving photographic documentation demonstrates that keys and padlocks were discovered, which would match Jewish tradition.

107 Čižmář and Šmíd 2000, 94; Kohoutek et al. 2000, 110; Unger 2002, 46; Wallisová 2009, 60.

108 Mikulkova 2011, 32 [no number].
In the light of ethnographic discoveries from the turn of the $19^{\text {th }}$ and $20^{\text {th }} \mathrm{c}$. and of post-war oral narratives of eyewitnesses to this tradition, padlocks were deposited into graves as locked, which is generally in accordance with archaeological discoveries. Recorded cases of opened padlocks are results of destruction of finds caused by deposition (Fig. 7). It can be supposed that padlocks previously used in household were not used for this purpose. This is due to the fact that according to a binding interpretation a deposition of any property into the grave would result in the death of its owner within a year ${ }^{109}$. The use of decoy artefacts in lieu of padlocks can be seen as a result of a long duration of this habit. This is suggested by archaeological discoveries and by depictions of locked gates, doors and padlocks (Fig. 6) which can sometimes be found on matzevas as

109 Chajes 1928, 319; Tuszewicki 2015, 468. 
a reminiscence of the past tradition ${ }^{110}$. Such depictions are, however, sporadic in the $19^{\text {th }} \mathrm{c}$. in cemeteries in Warszawa and are not known from other regions of Poland ${ }^{111}$.

\section{Attempt of explanation}

This habit was in use in Poland as late as the interwar period $^{112}$. In this time it was in all probability in decline, and it was used mainly in small centres by non-progressive and uneducated groups of the Jewish population ${ }^{113}$.

In the course of time the significance of this habit fell into oblivion. During interviews held after the Second World War interviewees stated that the aim of putting padlocks into graves was to prevent the dead person from: speaking, speaking bad things or rather talking about this world in the other world ${ }^{114}$.According to a relation of an inhabitant of Szadek, a padlock placed on the fourth plank in the grave was to stand for the closing of life of the dead ${ }^{115}$. Of course, care is recommended when using relations of witnesses of non-Jewish origin, who were not (as it is sometimes the case) direct participants of rituals but only observers or transmitters of contents preserved in memories of other persons. In line with this it is difficult to assess whether in Wyszogród there was really a habit among men to pray with a padlock attached to headgear, which was to stand for „being closed to the external world” and not allowing thoughts from this world to come ${ }^{116}$. An attempt at explaining this habit undertaken by the Congregation for the Jewish Faith proved to be rather mundane in its essence - the padlock was to symbolise protection of the grave against digging up or a repeated use of the place. Therefore, it stood for property ${ }^{117}$. Attention was also paid to non-ritual nature of this habit, which had a $16^{\text {th }} \mathrm{c}$. folk origin ${ }^{118}$. M. Piotrowski also dates the beginning of the habit of putting padlocks into graves to the $16^{\text {th }} \mathrm{c}$. He believes that this practice was related to the spread of practical Kabala and magic. This spread was accompanied by „demonisation” of the world, which was responsible for introducing horror and fear to Jewish necropoles $^{119}$. These sentiments were aftermath of Kabala thought, according to which the spheres of sacrum and profanum were a unity, and souls had an opportunity to transmigrate. Kabbalists, whose literary heritage was recorded between the

110 As it can be seen on matzevas from the 1920s in the cemetery in Okopowa Street in Warszawa - Fijałkowski 1989, 36.

111 Krajewska 1993, 36.

112 Fijałkowski 2003, 364.

113 Fijałkowski 1989, 36.

114 Fijałkowski 1989, 36. A relation from Jarocin - cf. a typescript from the archive of the Regional Museum in Jarocin, edited by E. Hejduk. Source: http://www.sztetl.org.pl/pl/article/jarocin1448/16,relacje-wspomnienia/32483,wspomnienia-o-cmentarzuzydowskim-w-jarocinie/ (access on 25 May 2016).

115 Cf. Wasilewska-Klamka 2012, 98.

116 Skrok 1991, 19.

117 Skrok 1991, 18.

118 Skrok 1991, 18-19.

119 Piotrowski 1987, 239. $12^{\text {th }}$ and $16^{\text {th }}$ c., popularised a new language of notions and a new interpretation of human actions, suspended between the forces of Good and Evil, holiness and uncleanness, the world of the dead and the eternal world ${ }^{120}$. The gilgul and the dybbuk have their origins in the Kabbalist theory of soul and mystical literature on the idea of holiness, as well as in a belief in existence of corridors connecting the world of the living and the world of the dead ${ }^{121}$. Any contact with the unclear sphere offered an opportunity for beings beyond control, who could infiltrate the human soul and bring insanity to him or her ${ }^{122}$.

Due to an obvious functional relation, the key and the padlock are included into the same group of symbolic connotations. Although the key has a much broader semantic scope, which is also related to opening, the meaning of the padlock is opposite, as related to closing. In the funeral context it points to a final end of temporality, departure with no return ${ }^{123}$. In relation to this, an expression „to hide away under seven locks" is used as a synonym for funeral ${ }^{124}$.

On the plank covering the dead body a lock-shaped branch was also sometimes placed - the symbolic meaning was unchanged and on this occasion it was said: „May the earth close behind you.” The ritual of exclusion also stipulated farewell, which was to send a message on the termination of life, ceasing of one's participation in earthly matters and exclusion from membership in brotherhoods ${ }^{125}$.

A fear of death, which was a universal feeling in premodern times, intensified a need for symbolic consolidation of the border between the world of the living and the world of the death, and for blocking paths of contact between them. Therefore, the padlock was seen as an object stopping the death: Auch legt man ein zugemachtes Schloß mit in das Grab, damit anzudeuten, dass mit diesem der Tod beschlossen werden, und aufhören solle ${ }^{126}$.

The key and padlocks in Ashkenazi folklore occur as means with counteracting and preventive properties. Numerous medical recipes referred to this scheme - opening, that is liberating and unbinding, as well as locking, that is terminating and blocking. Such an idea is perhaps related to a principle simila similibus curantur and contraria contrariis curantur, which was widespread in European folk medicine ${ }^{127}$. In line with this principle, placing a key to one's neck stopped nosebleed ${ }^{128}$, and a small unused key suspended on the neck of a child protected it from the return

120 Wodziński 1992, 22-23; Elior 2014, 50-51.

121 Elior 2014, 53-54.

122 Elior 2014, 89-90.

123 Piotrowski 1987, 235-237; Jan Jagielski - http://www.jhi. pl/psj/grob_zydowski. Access on 23 May 2016.

124 Tuszewicki 2015, 56.

125 Tuszewicki 2015, 468.

126 Krünitz 1800, 572. Cf. Bächtold-Stäubli and Hoffmann-Krayer 2000a, 1094; Bächtold-Stäubli and Hoffmann-Krayer 2000b, 830.

127 Cf. Tuszewicki 2015, 191.

128 Segel 1897, 55. 

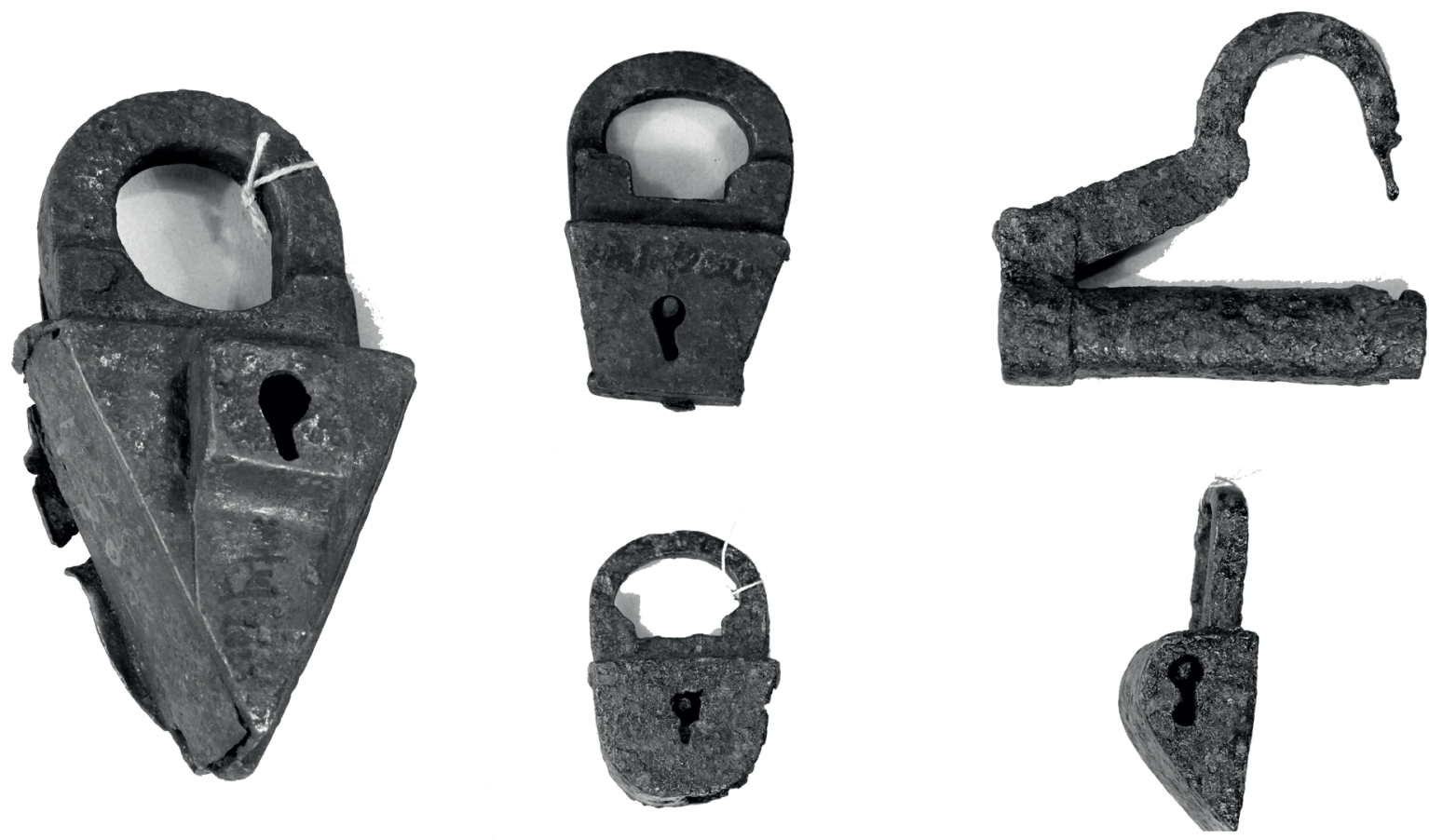

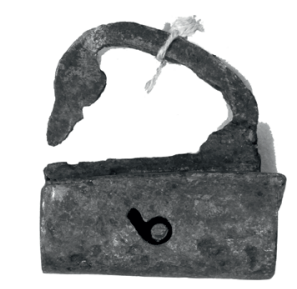

0
$10 \mathrm{~cm}$

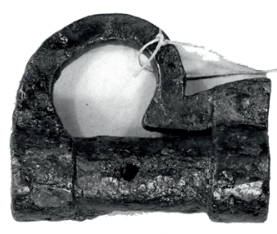

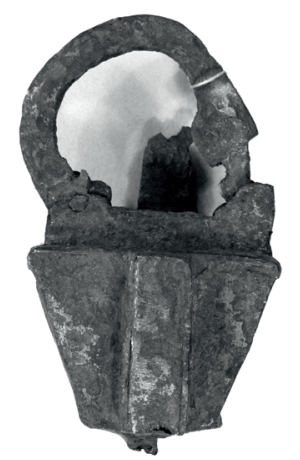

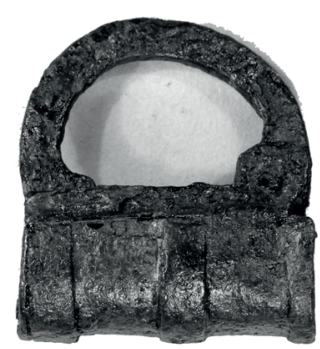

Fig. 7. Selection of padlocks discovered in the Jewish cemetery in Sanok. Photo J. Słomska, adapted by K. Skóra.

of disease ${ }^{129}$. These artefacts played a vital apotropaeic role in the period of childbirth and puerperium. A locked padlock was suspended on the door of the room where the puerpera and the suckling rested. A key to this padlock was hidden away. This procedure was to protect against bewitchments and demons ${ }^{130}$. During the childbirth doors and drawers must be open to „make the way for the newborn”131.

In Ashkenazi communities the key was also believed to be a remedy for suffering of the dying person. Placing a synagogue key under a pillow was to bring relief ${ }^{132}$. The

129 Segel 1897, 56.

130 Lilientalowa 1927, 13.

131 Segel 1897, 58; Die Thüren und Schubladen macht man auf, um „dem neugeborenen Kinde einen Weg zu bahnen“. Die Schlösser müssen sämtlich geöffnet sein, ebenso die Ohrgehänge, da sich so auch „die Gebärmutter leichter öffnet“. Diese Sitte ist auch bei den Juden allgemein verbreitet - Temesvary 1900, 53.

132 Segel 1897, 53. The same procedure was also believed to be a remedy in the case of difficult childbirths - Temesváry 1900, 60. time of agony was believed to be dangerous for many reasons ${ }^{133}$. Family and friends attempted at protecting the dying person and themselves in many ways ${ }^{134}$. Household members were in danger of misfortune, which could result from improper proceeding with the dead person or abstaining from traditional rituals in the course of preparation of the death body or during the funeral ceremony ${ }^{135}$.

In traditional folk beliefs anxiety was provoked by the Angel of Death, the dybbuk ${ }^{136}$, that is the soul of a dead

133 Cf. Tuszewicki 2015, 448, 457.

134 Pakentreger 1987, 40-14.

135 Any superabundance (too excessive mourning of the dead, too frequent visits to his or her grave) could cause dangerous consequences.

${ }^{136}$ Harmfulness of the dybbuk was believed to be much more disturbing than that of the gilgul, that is an erring and wandering soul of a sinner, trying to stick to objects and living beings - Tuszewicki 2015, 131-132. 

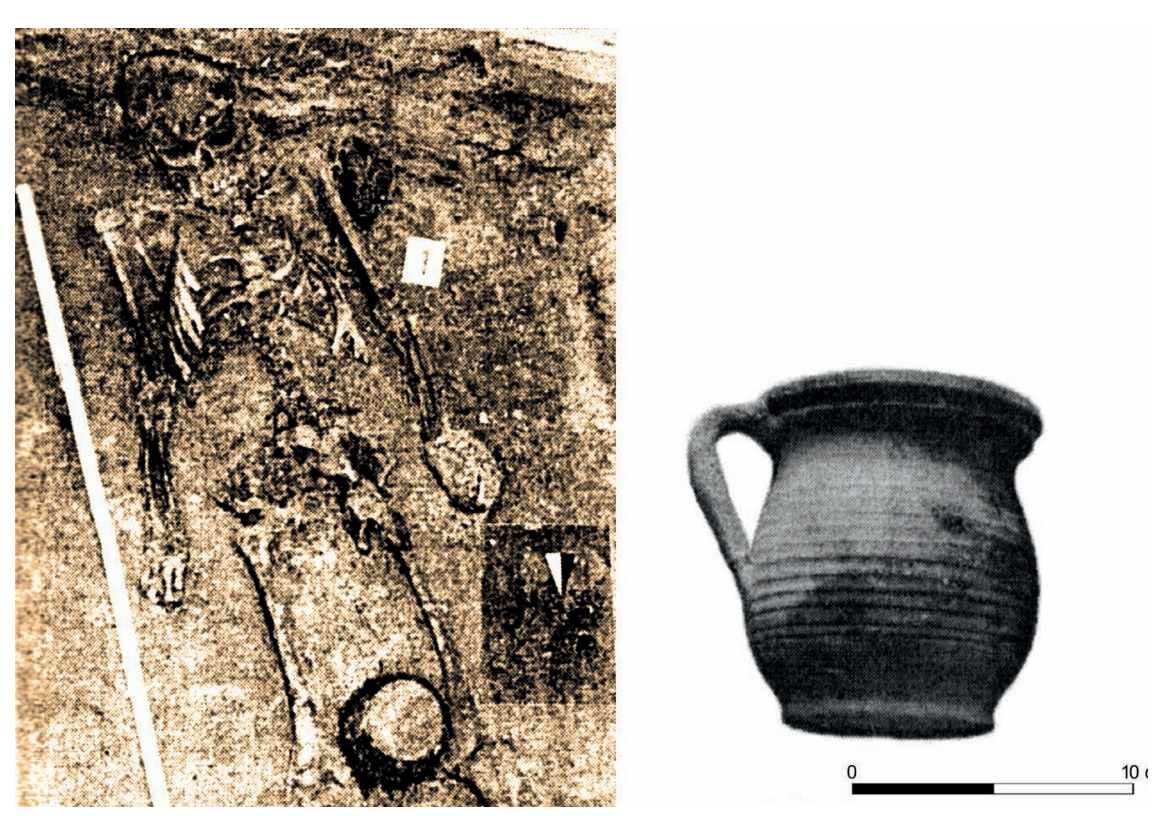

Fig. 8. Jewish cemetery in Wilno. Burial of a teenager with a vessel placed upside down. After Žukovskis 2000, Figs. 6-7. person $^{137}$, as well as demons roaming around the funeral procession $^{138}$. The dead body and the coffin were the main objectives of their attacks, especially if the dead was a wrongdoer during his or her life ${ }^{139}$. Many acts which were undertaken before the funeral were seen as anti-demonic procedures. Until they strike with a spade, the end of the man is unknown (Yiddish - Kol zman me klapt nit mit der lopetke, West men nit dem sof fun menczn $)^{140}$. A key, black bread with salt and a small tin plate were seen as remedies for flatulence of the dead and means of protection against unclean forces. The house of the dead was also to be locked, in order to prevent his or her soul from returning ${ }^{141}$.

Anxiety was also provoked by mors immatura. The death of small children was perceived as a result of activity of demons, or a consequence of $\operatorname{sins}^{142}$. In order to obviate the risk of the next deaths of children in the family, preventive means were used - among others, the dead body was carried out through the window and it was not carried to the cemetery in procession. Instead of it, the dead child was deposited into the grave as a qorban, that is an offering by its father. A locked padlock was thrown into the grave, while

${ }^{137}$ In the light of the analysis of Jewish legends it was first of all people who were shifted by the society to the margin that were endangered by possession by the dybbuk. Rachel Elior sees dybbuks as a „disease”, which was contracted by the betrothed, especially by fiancées. This was a way to escape from an unwanted and pre-arranged marriage. In result of this, the possessed woman was exempt from customary norms - Elior 2014, 56 ff., 69.

138 Tuszewicki 2015, 449-451.

139 Tuszewicki 2015, 465.

140 Tuszewicki 2015, 457.

141 Lilientalowa 1904, 108; Goldberg-Mulkiewicz 1986, 104-105.

${ }^{142}$ Dead bodies of small children were buried in veils, pillows, sacks, baskets and sometimes in cradles. There were no talks about the dead offspring and no mourning of newborns was stipulated. Otherwise, there was a danger of coming of the Angel of Death, lurking for the next children - cf. Tuszewicki 2015, 467. a key was placed next to the head or was taken away ${ }^{143}$. R. Lilientalowa explains that the aim of this was to make the earth close behind the dead.

Some of the afore-mentioned procedures were believed to be effective preventive means to stop plague, which was thought to possess a demonic shape. In the case of an epidemic of cholera the dead were carried away through windows ${ }^{144}$. Other means which were believed to have preventive power were so-called measuring of graves with a cord or linen (Yiddish - kvorim mestn), that is a symbolic fencing off the death with a prayer ${ }^{145}$, or ploughing a furrow around the settlement or part of the town from which the plague came ${ }^{146}$. The latter habit, evidenced in the Slavic population, was in all probability borrowed by their Jewish neighbours ${ }^{147}$. M. Tuszewicki believes that such cases of borrowings rather occurred in periods of extreme danger to life ${ }^{148}$. A genuine Jewish remedy was a ceremony of the „black wedding” (Yiddish - shvarts khasene, shvarts khupe) or a marriage of a couple of poor or lame persons in the cemetery. The use of this habit is testified to as late as during the Second World War ${ }^{149}$. Hanging a locked padlock on the door and „abandoning” the key was also to protect against plague $^{150}$. There is also ethnographic evidence that a large key was deposited into the grave of the first person who died in such circumstances, so that such a person „,could

$\begin{array}{ll}143 & \text { Lilientalowa 1927, } 45 . \\ 144 & \text { Tuszewicki 2015, } 468 . \\ 145 & \text { Tuszewicki 2015, } 122,472 . \\ 146 & \text { Tuszewicki 2015, } 268 . \\ 147 & \text { Libera 2003, 97; Tuszewicki 2014, } 54 . \\ 148 & \text { Tuszewicki 2014, } 54 . \\ 149 & \text { For this rite on the basis of memory books cf. Schiller } 2011 .\end{array}$ There is also evidence that objects which were to symbolise an epidemic were buried in the cemetery. This took place, e.g., in Nowe Miasto nad Pilicą. Burying of a small bell and a door was to secure a transfer of cholera to another place - Tuszewicki 2015, 475.

150 Segel 1897, 54. 
lock the grave behind himself or herself" ${ }^{151}$. Furthermore, there is evidence for putting a pot upside down on the grave, or for destroying the bier ${ }^{152}$. On the other hand, archaeological confirmation of such habits is rare. Therefore, of special significance is a discovery of a vessel, placed in this way between the legs of a died teenager. This discovery was made in a $16^{\text {th }}$ c. Jewish burial in Wilno (Fig. 8) ${ }^{153}$.

It can be assumed that a single padlock in fact meant a „closing” in the most general sense. If a few padlocks were deposited into one burial, as it is testified to in some cemeteries, it stood for a greater magical power and may have had another meaning, e.g., related to epidemics etc. It is possible that an intensification of impact was ascribed to iron, from which padlocks were made. Iron, analogously to fire, was believed to be very effective in anti-demonic practices ${ }^{154}$.

\section{Mutual inspirations in folk culture}

It must be stressed that deposition of padlocks into grave is evidenced by archaeological discoveries from Christian cemeteries. These are Medieval and Early Modern Period cemeteries, not only from Poland ${ }^{155}$, but also from, among others, Germany ${ }^{156}$, Bohemia ${ }^{157}$, and Slovakia ${ }^{158}$. The presence of such artefacts is first of all seen as part of antidemonic practices and a remedy to stop an epidemic ${ }^{159}$.

It is underlined in literature that this habit may have been borrowed by the Jews from the Slavic population. However, on account of the fact of a higher number of testimonies of this rite from Jewish necropoles, a reverse direction of inspiration should be assumed.

Hundreds of years of neighbourhood of the Jewish population and the Christians in Eastern Europe must have led to assimilation or acculturation in some aspects of life. Folk beliefs are a convenient subject for research. A syncretistic nature of folk rites was already known to pioneers of ethnography ${ }^{160}$. It must remained unanswered, however, whether these inspirations were always intentional or not. On the other hand, intentionality is testified to in numerous cases of borrowings, such as, e.g., the use of Slavic

151 Chajes 1928, 323-324; Tuszewicki 2015, 468. The presence of the key in the grave is also explained in another way - as a symbolic closing of a period of bad luck, brought by the death to the family - Nordmann 1906, 18. Keys were also deposited into graves of persons who died with no children - Fijałkowski 1989, 37; Fijałkowski 2003, 365.

152 Chajes 1928, 323; Tuszewicki 2015, 468.

153 Žukovskis 2000

154 Tuszewicki 2015, 221. Iron artefacts, including knives, needles, or small keys, were protective or healing means which were used for children - Lilientalowa 1927, 35.

155 For examples cf. Komski et al. 2014, 50, footnote 4; Krzepkowski et al. 2015, 345-349, Fig. 8.

${ }_{156}$ Wittkopp 1997a, 175; Wittkopp 1997b, 812, 814; Biermann 2008, 45-46.

157 Dušeková 1980, 442 (Fig.), 443.

158 Ciszewski 1911; Komski et al. 2014, 50, footnote 4.

159 Unger 2002, 46; Krzepkowski et al. 2015.

160 Cf. Bar-Itzhak 2010, 14-26. incantations by the Jews for the purpose of healing ${ }^{161}$, or taking to means from the Ashkenazi world by the Slavs ${ }^{162}$. A similar power was attributed to means which were considered as taboo, ritually unclean or even detestable ${ }^{163}$. Jewish people eagerly sought help from alien healers ${ }^{164}$, which certainly favoured an adaptation of Slavic recipes against illnesses, demons, evil eye, etc. The use of alien means did not mean at all that these would be applied for a purpose for which they were intended in the environment where they originated, as it is the case with cross pendants or medallions with the Holy Virgin ${ }^{165}$. Alien folk superstitions, although condemned by rabbis, were paradoxically often held for remedies in especially difficult cases ${ }^{166}$. According to M. Tuszewicki, Polish-Jewish contacts with regard to practices of folk medicine were characterised with a principle: the farther from towns, the greater intensity of contacts ${ }^{167}$.

In contrast to a long-lasting opinion about a cultural insularity of the Jewish Diaspora ${ }^{168}$ and a propagated hermetic image of their culture ${ }^{169}$, which did not yield to alien influences, the Jewish population did not live in a tightly closed enclave. To some degree, there were actual mutual „inspirations” between Jewish and Slavic folklore ${ }^{170}$. We can also expect such influences in the funeral sphere and the period of mourning, but it is difficult to assess their nature ${ }^{171}$. What was shared by both cultures was, e.g., a belief in noxious power of some dead persons, with regard to whom identical preventive means were applied, that is, burying with their faces down ${ }^{172}$.

Since the 1980s, when a model of polysystem of culture started to spread in scholarship, a theory of the shtetl as a cultural microcosm or a Jewish island in a nonJewish sea was also revised ${ }^{173}$. A new perspective of contact allows to see it as a place of mutual relations and interactions, and evidence for this intercultural communication is provided by, among others, folklore ${ }^{174}$. In circumstances of folk culture even other-languageness was not an obstacle in

161 Tuszewicki 2015, 207. In order to obviate the risk of death of a sucking, also alien rituals were considered helpful. Even baptising of children for this purpose is testified to - Tuszewicki 2015, 454 , footnote 54 , with relevant literature references.

162 Cf., e.g., Tuszewicki 2015, 374, footnote 37. On mezuzot considered by Polish peasants as a remedy for ague cf. Tuszewicki 2014, 40-41, footnote 63.

163 Tuszewicki 2015, 89.

164 Tuszewicki 2015, 114.

165 Tuszewicki 2015, 115.

166 Tuszewicki 2015, 84.

167 Tuszewicki 2014, 48.

168 Cf., e.g., Skrok 1991, 18.

169 Cf. remarks of Bar-Itzhak 2004, 91.

170 An example is a belief about a demonic nature of Plica Polonica, which was shared by both populations - Tuszewicki 2015, 257-260.

171 Goldberg-Mulkiewicz 1986, 103, 107, footnote 17.

172 Lilientalowa 1904, 109; Lilientalowa 1927, 13.

173 Prokop-Janiec 2013, 10.

174 Prokop-Janiec 2014, 9-12. 
communication between separate communities ${ }^{175}$. In spite of obvious differences between both cultures, they share common codes of values, which derive from the European heritage and encompass not only the sphere of science or medicine, but also that of magic ${ }^{176}$.

The idea of deposition of padlocks into graves was initiated probably at the turn of the Middle Ages and the Modern Period and commenced to decline in the early $20^{\text {th }} \mathrm{c}$. However, it was still maintained by Jewish inhabitants of villages and small towns, and its sense became obliterated in decades before the Second World War. On the one hand, this obliteration (or simplification) of sense was favoured by the long tradition of this habit. In result of it, it was possible to replace one symbol with another or, that is, to use decoys. Significances of this habit which are suggested by interviewees-eyewitnesses are superficial. Therefore, the earliest sources for Jewish ethnography must remain the main point of reference. This superficiality finds its analogy, among others, in the use of so-called written amulets by the Jewish folk. These amulets, however, were treated as a magical means only, with no understanding or knowledge of their religious sense, which was known solely to learned Kabbalists ${ }^{177}$.
In traditional Eastern European communities the reality was not closed within its physical dimension ${ }^{178}$, and the folk culture and demonology (which was part of the former) were not systematised knowledge ${ }^{179}$. Therefore, there was room for improvisation and testing of remedies. Olga Goldberg-Mulkiewicz, while discussing funeral rites and beliefs concerning death, remarked that in the course of time, due to scattering of Jewish communes and their isolation, rites in larger Jewish clusters had commenced to vary. This occurred in spite of the fact that these rites were rooted in philosophical foundations of the Jewish religion and in imperatives formed by this religion. It is difficult to identify the origin of these „novelties" in the sphere of beliefs, as they lack a clear justification in religious norms ${ }^{180}$. It is therefore worth considering whether a notable intensification of certain habits in the Polish lands is a result of the state of research. On the other hand, an explanation may partially be found in the opinion of Tobias Cohn. In the beginning of the $18^{\text {th }} \mathrm{c}$. he stated that there is no other country where people would more intensively deal with demons, amulets, incantations, names and dreams than the Commonwealth of Both Nations ${ }^{181}$.

\section{Bibliography}

Alder C., Matt Ch. Ph. 2010. Der mittelalterliche Friedhof der ersten jüdischen Gemeinde in Basel. Ausgrabungen in Kollegiengebäude der Universität. Mit einem numismatischen Beitrag von Beatrice Schärli und Michael Matzke. Materialhefte zur Archäologie in Basel 21. Basel.

Bächtold-Stäubli H., Hoffmann-Krayer E. 2000a. Grabbeigabe. In: H. Bächtold-Stäubli (ed.), Handwörterbuch des deutschen Aberglaubens 3. Berlin, New York, 1082-1103.

Bächtold-Stäubli H., Hoffmann-Krayer E. 2000b. Jude, Jüdin. In: H. Bächtold-Stäubli (ed.), Handwörterbuch des deutschen Aberglaubens 4. Berlin, New York, 808-833.

Bar-Itzhak H. 2004. Folklore As An Expression of Intercultural Communication Between Jews and Poles - King Jan III Sobieski in Jewish Legends. „Studia Mythologica Slavica” 7, 91-106.

Bar-Itzhak H. 2010. Pioneers of Jewish Ethnography and Folkloristics in eastern Europe. Ljubljana.

Biegeleisen H. 1930. Śmierć w obrzędach, zwyczajach i wierzeniach ludu polskiego. Warszawa.

Biermann F. 2008. Archäologische Zeugnisse magischer Vorstellungen in mittelalterlichen und frühneuzeitlichen Bestattungswesen Vorpommerns und benachbarter Gebiete. In: A. Majewska (ed.), Czary i czarownictwo na Pomorzu. Materiały z konferencji naukowej, która odbyła się w dniach 17-18 maja 2007 r. w Marianowie. Stargard, 39-57.

Blanchard Ph., Georges P., de Mecquenem C. 2009. Le cimetière juif au moyen âge. Un lieu d'exclusion? „Archéopages” 25 , 14-23.

Blanchard Ph., Georges P. 2010. Le cimetière juif de Châteauroux: informations historiques, résultats archéologiques et approche comparative. „Revue de l'Académie du Centre” année 2010, 33-57.

Borowska-Strugińska B. 2005. Uwagi na temat niektórych elementów obrzadku pogrzebowego ludności żydowskiej pochowanej na cmentarzysku w Brześciu Kujawskim. In: W. Dzieduszycki, J. Wrzesiński (eds.), Do, ut des - dar, pochówek, tradycja. Funeralia Lednickie 7. Poznań, 233-237.

Chajes Ch. 1928. גלייבונגען און מנהגים אין פארבינדונג מיטן טויט [Glejbungen un minhogim in farbindung mitn tojt]. [Filologisze Szriftn] 2, 281-328.

\footnotetext{
175 Stomma 1986, 62-63.

176 Prokop-Janiec 2014, 13; Tuszewicki 2014, 27.

177 Cf. Tuszewicki 2014, 53.
}

\author{
178 Tuszewicki 2015, 228. \\ 179 Tuszewicki 2015, 282. \\ 180 Goldberg-Mulkiewicz 1986, 103; cf. Wodziński 2008. \\ 181 After Tuszewicki 2015, 79
}


Ciszewski S. 1911. Czaszki ludzkie z kłódkami. „Lud” 17, 19-30.

Cymbalak T., Staňková V., Polakovič D. 2015. The Jewish Garden in the New Town of Prague. New lessons learned from the archaeological investigations undertaken by the National Heritage Institute in the Capital City of Prague. In: E. Doležalová et al. (eds.), Juden in der mittelalterlichen Stadt. Der städtische Raum im Mittelalter - Ort des Zusammenlebens und des Konflikts. Jews in the medieval Town. Urban space in the Middle Ages - a place of coexistence and conflicts. Colloquia mediaevalia Pragensia 7. Prague, 149-168.

Čižmář Z., Šmíd M. 2000. Vývoj Prostějova v archeologických a historických pramenech v období10.-16. století. „Archaeologia historica“ 25, 77-102.

Dušeková S. 1980. Cintorín z 15.-17. stor. v Smoleniciach (Archeologicko-historická interpretácia). „Slovenský národopis“ 28 (3), 433-454.

Elior R. 2014. Dybuki i kobiety żydowskie w historii społecznej, myśli mistycznej i folklorze. Gnieźnieńskie Studia Europejskie - Seria monografie 19. Poznań, Gniezno.

Fijałkowski P. 1989. Obrzadek pogrzebowy Żydów polskich w świetle badań archeologicznych. O potrzebie badań archeologicznych nad historia i kulturą Żydów w Polsce. „Biuletyn Żydowskiego Instytutu Historycznego” 3 (151), lipiec-wrzesień 1989, 25-42.

Fijałkowski P. 2003. Obrzędy pogrzebowe Żydów polskich w XVI-XIX w. w świetle badań archeologicznych. In: W. Dzieduszycki, J. Wrzesiński (eds.), Kobieta - śmierć - mężczyzna. Funeralia Lednickie 5. Poznań, $361-371$.

Fischer A. 1921. Zwyczaje pogrzebowe ludu polskiego. Lwów.

Ganzfried S. 1973. קיצור שלחן ערוך. Tel Awiw.

Głąb Z. 2015. Socjotopografia Lutomierska (XIII-XVIII w.). Wrocław.

Goldberg-Mulkiewicz O. 1986. Obrzędy żałobne i pogrzebowe Żydów polskich. „Polska Sztuka Ludowa” 40 (1-2), $103-107$.

Harck O. 2004. Die archäologischen Funde zur jüdischen Geschichte in Mitteleuropa - Ein Überblick. In: E. Wamers, F. Backhaus (eds.), Synagogen, Mikwen, Siedlungen: Jüdisches Alltagsleben im Lichte neuer archäologischer Funde. Schriften des Archäologischen Museums Frankfurt 19. Frankfurt 25-40.

Harck O. 2014. Archäologische Studien zum Judentum in der europäischen Antike und der zentraleuropäischen Mittelalter. Schriftenreihe der Bet Tfila - Forschungsstelle für jüdische Architektur in Europa 7, A. Cohen-Mushlin, H. H. Thies (eds.). Petersberg.

Hońdo L. 2011. Dom przedpogrzebowy przy żydowskim nowym cmentarzu w Krakowie. Kraków.

Jażdżewski K. 1951. Cmentarzysko wczesnośredniowieczne w Lutomiersku pod Łodziq w świetle badań z r. 1949, „Materiały Wczesnośredniowieczne" 1 (1949), 91-191.

Kohoutek J., Proházka R., Unger J., Zatloukal R. 2000. Mittelalter und Neuzeit. In: M. Čižmář, K. Geislerová, J. Unger (eds.), Výzkumy - Ausgrabungen 1993-1998. Brno, 106-113.

Komski A., Kurasiński T., Skóra K. 2014. Kłódki ze zniszczonego cmentarza sanockiego. Przyczynek do badań nad żydowska obrzędowościa pogrzebowa w przeszłości. „Rocznik Sanocki” 11, 49-62.

Krajewska M. 1993. A Tribe of Stones. Jewish Cemeteries in Poland. Warsaw.

Krügel M., Kirsch E. 2005/2006. Der „Judenkirchhof“ zu Buckow, Lkr. Märkisch-Oderland. „Veröffentlichungen zur brandenburgischen Landesarchäologie“ 39/40 (2007), 289-297.

Krünitz J.G. 1800. Enzyklopädie, oder allgemeines System der Staats-Stadt-Haus-und Landwirtschaft, wie auch der Erdbeschreibung, Kunst- und Naturgeschichte, in alphabetischer Ordnung 73. Brünn.

Krzepkowski M., Sikorski A., Wrzesińska A. 2015. XVII-wieczny pochówek zbiorowy z kłódka z cmentarzyska w Skokach, pow. wagrowiecki, woj. wielkopolskie. Próba interpretacji. In: A. Michałowski, M. Teska, M. Żółkiewski (eds.), Viator per devia scientiae itinera. Studia nad problematyka okresów przedrzymskiego, rzymskiego, wędrówek ludów i wczesnego średniowiecza. Seria Archeologia 53. Poznań, 339-353.

Libera Z. 2003. Znachor w tradycjach ludowych i popularnych XIX-XX wieku. Wrocław.

Lieben S. H. 1933. Jüdische Grabsteine in den historischen Ländern. In: Die jüdischen Denkmäler in der Tschechoslowakei. Veröffentlichungen der Denkmalskommission des obersten Rates der jüdischen Kultusgemeinde-Verbände in Böhmen, Mähren und Schlesien. Prag, 19-30.

Lilientalowa R. 1898. Przesądy żydowskie. „Wisła” 12, 277-284.

Lilientalowa R. 1902. Życie pozagrobowe i świat przyszły w wyobrażeniach ludu żydowskiego. „Lud” 8, 350-353.

Lilientalowa R. 1904. Wierzenia, przesady i praktyki ludu żydowskiego. „Wisła” 18, 105-113.

Lilientalowa R. 1927. Dziecko żydowskie. Kraków.

Lilley J.M., Stround G., Brothwell D.R., Williamson M.H. 1994. The Jewish Burial Ground at Jewbury. The Archaeology of York 12/3: The Medieval Cemeteries. York.

Marcinkowska H. Żydowski pogrzeb w przedwojennej Polsce. Źródło: http://old.fzp.net.pl/pogrzeb2.html, access on 31 July 2012. 
Mikulkova B. 2011. Slavkov u Brna (okr. Vyškov), ul. Čs. Armády. In: Výroční zpráva 2010, Ústav Archeologické Památkové Péče Brno, V.V.I. Brno.

Nadolski A., Abramowicz A., Poklewski T. 1959. Cmentarzysko z XI wieku w Lutomiersku pod Łodzia. Acta Archaeologica Universitatis Lodziensis 7. Łódź.

Nordmann A. 1906. Über den Judenfriedhof in Zwingen und Judenniederlassungen im Fürstbistum Basel. „Basler Zeitschrift für Geschichte und Altertumskunde“ 6 (1), 1-33.

Pakentreger A. 1987. Od kolebki do zgonu. „Kalendarz Żydowski“ 1987-1988, 34-43.

Pinkas hakehillot Polin: entsiklopedyah shel ha-yishuvim ha-Yehudiyim le-min hivasdam ve- ad le-ahar Sho'at Milhemet ha-'olam ha-sheniyah (Pinkas Hakehillot: Encyclopedia of Jewish Communities, Poland, vol. I, Lodz and its region). D. Dabrowska, A. Wein (eds.), published by Yad Vashem. Jerusalem.

Piotrowski M. 1987. Próba rekonstrukcji obrządku pogrzebowego ludności żydowskiej na podstawie badań archeologicznych cmentarza w Wyszogrodzie, „Rocznik Mazowiecki” 9, 213-240.

Podgarbi B. 1990. Cmentarz żydowski w Łodzi. The Jewish Cemetery in Lodz. Łódź.

Prokop-Janiec E. 2013. Pogranicze polsko-żydowskie. Topografie i teksty. Kraków.

Prokop-Janiec E. 2014. Kulturowe i literackie kontakty polsko-żydowskie. In: E. Prokop-Janiec (ed.), Polacy - Żydzi. Kontakty kulturowe i literackie. Kraków, 9-21.

Pümpin C. Rentzel Ph. 2010. Untersuchungen der sogenannten „Palästina-Erde“. In: Alder C., Matt Ch. Ph., Der mittelalterliche Friedhof der ersten jüdischen Gemeinde in Basel. Ausgrabungen in Kollegiengebäude der Universität. Mit einem numismatischen Beitrag von Beatrice Schärli und Michael Matzke. Materialhefte zur Archäologie in Basel 21, Basel, 36-38.

Rozmus D. 2005. De Judeorum arte sepulcrali. Motywy artystyczne w żydowskiej sztuce sepulkralnej. Kraków.

Schiller R. 2011. Ceremonia ,czarnego wesela“ i jej opisy w księgach pamięci., מדרש. Pismo Żydowskie“ 6 (164) listopad/ grudzień 2011, 36-39.

Segel B. W. 1897. Wierzenia i lecznictwo ludowe Żydów. „Lud” 3 (1), 49-61.

Skrok Z. 1991. Kłódki symboliczne. Przyczynek do zwyczajów pogrzebowych Żydów polskich, „Polska Sztuka Ludowa” 45 (2) (213), 18-20.

Skrok Z. 1994. Kłódki w grobach. „Spotkania z zabytkami” 1994 (6), 25-26.

Spector Sh., Wigoder G. (eds.) 2001. The Encyclopedia of Jewish Life Before and During the Holocaust 2. New York.

Stomma L. 1986. Antropologia kultury wsi polskiej XIX w. Warszawa.

Temesváry R. 1900. Volksbräuche und Aberglauben in der Geburtshilfe und der Pflege des Neugeborenen in Ungarn. Leipzig.

Tuszewicki M. 2013. Dziecko jako przedmiot troski od chwili poczęcia do narodzin w świetle żydowskich poradników z przełomu XIX i XX wieku. In: A. Jeziorkowska-Polakowska, A. Karczewska (eds.), Żydowskie dziecko. Lublin, 75-84.

Tuszewicki M. 2014. Żydowska medycyna ludowa: pomiędzy swojskościa a obcością. In: E. Prokop-Janiec (ed.), PolacyŻydzi. Kontakty kulturowe i literackie. Kraków, 25-56.

Tuszewicki M. 2015. Żaba pod językiem. Medycyna ludowa Żydów aszkenazyjskich przełomu XIX i XX wieku. Kraków, Budapest.

Unger J. 2002. Pohřbívání v šestnáctém století. „Sborník prací Filozofické Fakulty Brněnskě Univerzity. Studia minora Facultatis Philosophicae Universitatis Brunensis” C49, 41-48.

De Vries S. Ph. 2000. Obrzędy i symbole Żydów. Kraków.

Vyšohlíd M. 2013. Archeologický výzkum v Jungmannově ulici dokončen. http://archaiapraha.cz/praha-cs/?acc=aktuality\&id=150 (accessed on 28 April 2016).

Wallisová M. S. 1998. Předběžná zpráva o 1. etapě záchranného archeologického výzkumu v prostoru býv. židovského hřbitova ve Vladislavově ul. na Novém Městě pražském. „Archaeologica Pragensia” 14, 141-148.

Wallisová M. S. 2009. Židovsky hřbitov ve Vladislavově ulici. „Staletá Praha” 25 (2), 54-65.

Wallisová M. S. 2011. Le cimetière juif medieval du quartier de Nové Město à Prague. In: P. Salmona, L. Sigal (eds.), LArchéologie du Judaïsme en France et en Europe. Paris, 273-286.

Wasilewska-Klamka B. 2012. Żydzi w Szadku - fragmenty wspomnień. „Biuletyn Szadkowski” 12, 87-106.

Wilczura A. 2010. Śmierć i życie pozagrobowe w żydowskich wierzeniach ludowych. „Studia Bliskowschodnie” 1 (4), 34-41. Wittkopp B. 1997a. Frühneuzeitliches Totenbrachtum. Ausgrabungen in der Dorfkirche und auf dem Friedhof von Rüdersdorf-Tasdorf, Landkreis Märkisch-Oderland, „Archäologie in Berlin und Brandenburg 1995-1996“, 174-176.

Wittkopp B. 1997b. Beigabenlose Neuzeit? Tracht- und Beigabensitte auf einem Dorffriedhof der Renaissance- und Barockzeit in Brandenburg. In: C. Becker et al. (eds.), Chronos. Beiträge zur prähistorischen Archäologie zwischen Nord- und Südeuropa. Festschrift für Bernhard Hänsel. Espelkamp, 809-817. 
Wodziński M. 1992. Dybuk. Z dokumentów Archiwum Głównego Akt Dawnych w Warszawie. „Literatura Ludowa” 1992 (6), 19-29.

Wodziński M. 2008. Jakie naprawdę byly wyobrażenia eschatologiczne ludu żydowskiego w Europie Wschodniej? Rekonesans badawczy. „Theologica Wratislaviensia” 3, 47-54.

Žukovskis R. 1998. Žvalgomieji tyrinejimai Vilniuje, tarp Rinktines ir Zveju gatviu. „Archeologiniai tyrinejimai Lietuvoje 1996 ir 1997 metais”. Vilnius, 441-443.

Žukovskis R. 2000. Žvalgomieji archeologijos tyrimai istoriniame Vilniaus žveju priemiestyje (1996, 1998 m). „Kultūros paminklai. Mokslinių straipsnių rinkinys“ 7, 62-68.

\section{Streszczenie}

\section{Zwyczaj wyposażania zmarłych w kłódki na tle obrzędowości funeralnej Żydów aszkenazyjskich}

Artykuł omawia rozpowszechniony wśród społeczności żydowskiej w Europie Środkowo-Wschodniej zwyczaj wyposażania zmarłych w kłódki. Podstawowym źródłem informacji o nim są badania archeologiczne. Problematycznie jawi się ustalenie genezy tego rytuału. Zwyczaj ten zaprezentowano na szerokim tle aszkenazyjskiej obrzędowości pogrzebowej z odniesieniem do ugruntowanych religijnie wierzeń związanych ze zmarłym i ze śmiercią oraz popularnych wyobrażeń ludowych, znanych z pionierskich prac etnograficznych z XIX i pocz. XX w. Podjęto próbę wieloaspektowego scharakteryzowania zjawiska, zwracając uwagę na możliwość wzajemnego przenikania się elementów żydowskiej i słowiańskiej kultury ludowej w zakresie m.in. remediów antydemonicznych czy antyepidemicznych. 
